\title{
Influence of the diet and grazing on adipose tissue lipogenic activities and plasma leptin in steers
}

\author{
Y. Faulconnier ${ }^{1}$, I. Ortigues-Marty ${ }^{1}$, C. Delavaud ${ }^{1}$, D. Dozias ${ }^{2}$, R. Jailler ${ }^{1}$, D. Micol ${ }^{1}$ \\ and Y. Chilliard ${ }^{1+}$ \\ ${ }^{1}$ INRA, UR1213 Herbivores, Site de Theix, F-63122 Saint-Genès-Champanelle, France; ${ }^{2}$ INRA, UE 326 Domaine de Borculo, F-61310 Le Pin-au-Haras, France
}

(Received 12 April 2007; Accepted 3 July 2007)

\begin{abstract}
The objectives of the two experiments were to determine the respective effects and interactions of diet type (grass v. maize diets) and physical activity (grazing v. zero grazing) on lipogenic enzyme activities and adipose cell size in subcutaneous, perirenal and intermuscular adipose tissues and on plasma metabolites and hormones in Charolais steers. After weaning, the steers were assigned to two (Experiment 1, $\mathrm{n}=24$ ) or three (Experiment 2, $\mathrm{n}=24$ ) groups, with steers in Experiment 1 grazed grass or indoors maize-silage-fed and steers in Experiment 2 grazed grass, indoors cut grass- or indoors maize-silage-fed. Both experiments lasted for 23 months. All grass-fed animals were fed grass silage during the two winter seasons. During the two summer seasons, steers fed on grass were rotationally grazed on a perennial rye-grass pasture while steers fed on cut grass were fed indoors on freshly cut grass alone. Steers fed on maize silage were fed maize silage indoors during the entire experiment. All animals were reared for similar body weight and growth rates and slaughtered at the same age (31 to 32 months). Activities of lipogenic enzymes were significantly lower in the three adipose tissue sites of steers fed cut grass compared with maize silage, although there were less-marked effects in intermuscular adipose tissue. Plasma insulin and glucose concentrations were also lower in steers fed cut grass whereas plasma leptin concentration was similar. As body fat content was not affected by nutritional treatment, it is suggested that the decrease in potential lipogenic activity was associated with the nature of the diet and not to differences in available net energy. In other respects, grazed grass compared with eating cut grass did not affect lipogenic enzyme activities but decreased plasma leptin concentrations in the older steers and increased plasma non-esterified fatty acids and glucose concentrations without affecting adipose tissue weight and adipose cell size.
\end{abstract}

Keywords: adipose tissue, grass diets, lipogenesis, maize silage, steers

\section{Introduction}

Different rearing factors (including breed, sex, age, diet) can modify meat and carcass quality in cattle. Among these rearing factors, dietary conditions are known to affect carcass characteristics by modifying the content and composition of adipose tissue (AT), especially when comparing beef produced in forage $v$. grain finishing systems (French et al., 2000). Consumers throughout Europe are showing a growing interest for meat produced from grass-fed ruminants, which is considered to be healthier and more natural than that obtained from grain-fed animals (Geay et al., 2001). Indeed, a grass-based diet compared with the maizesilage-based diet increased the polyunsaturated fatty acid

${ }^{\dagger}$ E-mail: yves.chilliard@clermont.inra.fr
(PUFA) to saturated fatty acid (SFA) ratio and decreased the n-6-to-n-3 PUFA ratio in intermuscular and subcutaneous AT (Noci et al., 2005). However, nutritional treatment can also affect the metabolism of bovine AT, with roughage diets resulting in decreased carcass fatness and AT lipogenesis compared with concentrate diets (Schoonmaker et al., 2004). These data have been explained on the basis of differences in energy intake. However, one study in ewes fed diets with the same energy density reported that lipogenesis was lower in the subcutaneous AT of ewes fed roughage compared with those fed a concentrate diet (Okine and Arthur, 1997). The first objective of the present study was therefore to evaluate the influence of a grass diet compared with a maize silage diet on AT lipogenesis in steers reared at the same growth rate. Moreover, one characteristic of animals produced on pasture is a higher 
Faulconnier, Ortigues-Marty, Delavaud, Dozias, Jailler, Micol and Chilliard

physical activity than those raised indoors. Thus, it is difficult to dissociate, at pasture, the respective effects of the nature of the diet and the activity of the animal, since the mobility of animals could decrease lipogenic activity and fat deposition, as has been observed in rodents (Nara et al., 1999; Faulconnier et al., 2004). Thus, our second objective was to compare the respective effects of feeding grass either at pasture or indoors. Lipogenic enzyme activities involved in de novo lipogenesis, fatty acid (FA) esterification, triglyceride uptake and adipose cell size were assessed in different AT sites (perirenal, intermuscular and/or subcutaneous AT) since regional differences have been reported in the responses of bovine AT deposits to dietary manipulations (Chilliard and Robelin, 1985; Gilbert et al., 2003; Bonnet et al., 2004). Other parameters linked to lipogenesis and adiposity, such as plasma glucose, nonesterified FA (NEFA), insulin and leptin, are also reported.

\section{Material and methods}

\section{Animals, diets and experimental design}

The two experiments were conducted at the INRA Le Pin-auHaras experimental farm in full compliance with national legislation on animal care and on experimentation on living animals.

Experiment 1: comparison of grazed grass-based and maize-silage-based diets on adipose tissue lipogenesis and plasma metabolites and hormones

Twenty-four Charolais steers weaned at 8 months of age were allotted into two treatment groups, i.e. either maize silage or grazed grass groups, with 12 animals in each group, based on birth weight, weaning weight and body condition score (scale of 0 (very thin) to 5 (very fat)). The animals were castrated at 9 months of age. The whole study lasted 23 months from weaning and covered two winter seasons and two summer seasons. The feeding value of the food ingredients and diets and the nutritional requirements of the animals were calculated according to INRA (1978) feeding standards. Steers of the maize-fed group were housed in open sheds with 12 animals per pen of $80 \mathrm{~m}^{2}$ and were fed maize silage (0.9 UFL, $50 \mathrm{~g}$ PDIN and $70 \mathrm{~g}$ PDIE per $\mathrm{kg}$ dry matter (DM)) with a small amount of wheat straw (0.4 UFL, $22 \mathrm{~g}$ PDIN and $44 \mathrm{~g}$ PDIE per kg DM) and rapeseed meal (1.1 UFL, $260 \mathrm{~g}$ PDIN and $165 \mathrm{~g}$ PDIE per $\mathrm{kg} \mathrm{DM}$ ) throughout the duration of the experiment. Over the last summer season, ingredient composition of the maize diet calculated on a dry matter basis averaged $72 \%$ maize silage, $17 \%$ wheat straw and $11 \%$ rapeseed meal, respectively. During the winter seasons, steers on the grass treatment were fed ad libitum grass silage (from a permanent pasture of perennial rye-grass ( $0.7 \mathrm{UFL}, 49 \mathrm{~g}$ PDIN and $52 \mathrm{~g}$ PDIE per $\mathrm{kg} \mathrm{DM}$ )) supplemented with a commercial concentrate (1.1 UFL, $111 \mathrm{~g}$ PDIN and $128 \mathrm{~g}$ PDIE per kg DM) and/or rapeseed meal (1.1 UFL, $260 \mathrm{~g}$ PDIN and $165 \mathrm{~g}$ PDIE per kg DM). Over the last winter season, grass silage, concentrate and rapeseed meal accounted for $85 \%, 11 \%$ and $4 \%$ of the total dry matter intake, respectively. During the two summer seasons, animals rotationally grazed on a perennial rye-grass pasture (estimated to have a mean value of 0.9 UFL, $94 \mathrm{~g}$ PDIN and $89 \mathrm{~g}$ PDIE per $\mathrm{kg} \mathrm{DM}$ ) without supplementation.

Experiment 2: Comparison of the effects of grazed grassbased, cut grass-based or maize-silage-based diets on adipose tissue lipogenesis and plasma metabolites and hormones

Twenty-four Charolais steers weaned at 8 months of age were allotted into one of the two treatment groups, with 8 and 16 animals to the maize silage and grass treatment groups, respectively, based on birth weight, weaning weight and body condition score. The animals were castrated at 9 months of age. The whole study lasted 23 months from weaning, and covered two winter seasons and two summer seasons. The animals were housed in open sheds, with eight animals per $80 \mathrm{~m}^{2}$ pen, except at pasture. The steers of the maize silage group were fed maize silage $(0.9 \mathrm{UFL}$, $50 \mathrm{~g}$ PDIN and $70 \mathrm{~g}$ PDIE per $\mathrm{kg} \mathrm{DM}$ ) with a small amount of wheat straw (0.4 UFL, $22 \mathrm{~g}$ PDIN and $44 \mathrm{~g}$ PDIE per $\mathrm{kg} \mathrm{DM}$ ) and rapeseed meal (1.1 UFL, $260 \mathrm{~g}$ PDIN and $165 \mathrm{~g}$ PDIE per $\mathrm{kg} \mathrm{DM}$ ) throughout the duration of the experiment. Over the last summer season, ingredient composition of the maize diet calculated on a DM basis averaged $73 \%$ maize silage, $15 \%$ wheat straw and $12 \%$ rapeseed meal, respectively. The animals on the two grass treatments were fed during the winter seasons ad libitum grass silage (from a permanent pasture of perennial rye-grass $(0.83 \mathrm{UFL}, 61 \mathrm{~g}$ PDIN and $61 \mathrm{~g}$ PDIE per $\mathrm{kg}$ DM)) with a small amount of wheat straw (0.4 UFL, $22 \mathrm{~g}$ PDIN and $44 \mathrm{~g}$ PDIE per $\mathrm{kg} \mathrm{DM})$ and supplemented with a commercial concentrate (1.1 PDIE, $111 \mathrm{~g}$ PDIN and $128 \mathrm{~g}$ PDIE per $\mathrm{kg} \mathrm{DM}$ ) and/or rapeseed meal (1.1 UFL, $260 \mathrm{~g}$ PDIN and $165 \mathrm{~g}$ PDIE per $\mathrm{kg}$ DM). Over the last winter season, grass silage, straw and concentrate accounted for $85 \%, 12 \%$ and $3 \%$, of the total DM intake, respectively. During the first summer season, the animals of the grass treatment were grazed rotationally on a perennial rye-grass pasture. For the second summer season, the animals were split into two homogenous groups of eight animals each, on the basis of their age and live weight. The first group (grazed grass) was finished by rotational grazing of a perennial rye-grass pasture $(0.85$ UFL, $88 \mathrm{~g}$ PDIN and $86 \mathrm{~g}$ PDIE per $\mathrm{kg}$ DM), without any supplementation. The second group (cut grass) was offered ad libitum fresh cut grass daily, coming from the same plot as that used by the grazing group.

In these two experiments, feed intake of the grazing animals was estimated by determining the average grass height at entry and exit for each plot as well as the average weight of grass cut over a $30 \mathrm{~m}^{2}$ area from each plot. Daily feed intake of steers fed indoors was determined by the daily weighing of feed allowances and refusals. Live weights were measured every 2 weeks. Feeding allowance of the maize-silage-fed group was adjusted every 2 weeks 
Table 1 Body weight, average daily gain and fat weight before slaughter in Charolais steers in Experiments 1 and $2^{+}$

\begin{tabular}{|c|c|c|c|c|}
\hline & \multicolumn{2}{|c|}{ Grass } & \multicolumn{2}{|c|}{ Maize } \\
\hline & Cut & Grazed & Silage & s.e. \\
\hline \multicolumn{5}{|l|}{ Experiment 1} \\
\hline Age (months) & & 31.7 & 31.6 & 0.32 \\
\hline Final body weight $(\mathrm{kg})$ & & 763 & 780 & 16.5 \\
\hline $\begin{array}{l}\text { Average daily gain (g/day) } \\
\text { before slaughtering }^{\ddagger}\end{array}$ & & 1037 & 792 & 124 \\
\hline Total fat $(\mathrm{kg})$ & & 101 & 98 & 4.34 \\
\hline Internal adipose tissue ${ }^{\S}(\mathrm{kg})$ & & 24.1 & 24.6 & 1.33 \\
\hline Perirenal adipose tissue $(\mathrm{kg})$ & & 8.63 & 8.17 & 0.70 \\
\hline \multicolumn{5}{|l|}{ Experiment 2} \\
\hline Age (months) & 32.2 & 32.1 & 32.2 & 0.43 \\
\hline Final body weight $(\mathrm{kg})$ & 778 & 782 & 809 & 16.8 \\
\hline $\begin{array}{l}\text { Average daily gain (g/day) } \\
\text { before slaughtering }\end{array}$ & 842 & 997 & 827 & 69.7 \\
\hline Total fat $(\mathrm{kg})$ & 100 & 105 & 108 & 4.89 \\
\hline Internal adipose tissue ${ }^{\S}(\mathrm{kg})$ & 25.7 & 27.1 & 30.1 & 1.52 \\
\hline Perirenal adipose tissue $(\mathrm{kg})$ & 8.87 & 9.19 & 11.0 & 0.86 \\
\hline
\end{tabular}

${ }^{\top}$ There was no significant between-treatment effect $(P>0.10)$.

${ }^{\ddagger}$ Measured between 26 and 32 months of age (last summer season).

\$Perirenal, peritoneal, mesenteric and pericardiac adipose tissues.

so that animals would show the same average daily gain as those of the grazed grass group. The animals were then slaughtered at the end of the second grazing season, at the same final age (31 to 32 months of age) and at the same final average live weight (Table 1).

During each treatment period (i.e. at $400,480,780$ and 840 days of age) and just prior to slaughter (at 964 days of age), jugular blood samples were collected after a night fast into EDTA-containing tubes and centrifuged. Plasma was collected and frozen at $-20^{\circ} \mathrm{C}$ until analysis of plasma leptin, insulin, glucose and NEFA. Just after slaughter, samples of subcutaneous, perirenal and/or intermuscular AT were taken and either immediately placed at $37^{\circ} \mathrm{C}$ for adipocyte volume determination or stored at $-80^{\circ} \mathrm{C}$ until analysis of lipogenic enzyme and lipoprotein lipase (LPL) activities. Subcutaneous AT was dissected on the rump in front of the tail and intermuscular AT from the longissimus thoracis muscle. Total fat (i.e. carcass fat depots plus internal fat depots) was also determined. Internal fat depots (i.e. perirenal, peritoneal, mesenteric and pericardiac AT) were weighed and carcass fat depots (i.e. essentially intermuscular, subcutaneous and intramuscular AT) were estimated from the composition of the sixth ribcut by regression equations, as described by Robelin and Geay (1977).

\section{Plasma metabolites and hormones}

Plasma glucose and NEFA concentrations were determined enzymatically by the glucose dehydrogenase method (Glucose RTU kit; BioMérieux, Lyon, France) and the
acyl-CoA Synthetase method (Wako-Unipath NEFA-C kit; Oxoid, Dardilly, France), respectively, as described by Ferlay and Chilliard (1999).

The leptin content of blood plasma was analysed in duplicate with an ovine-specific RIA that has been validated for the bovine species (Delavaud et al., 2002). Withinand between-assay variations were $6.5 \%$ and $7.6 \%$, respectively.

Plasma insulin concentrations were assayed in duplicate using a commercially available porcine RIA kit (Cis Bio International, Gif sur Yvette, France) validated for bovine plasma. Within- and between-assay variations were $5.4 \%$ and $6.4 \%$, respectively.

\section{Tissue measurements}

Adipose tissue cellularity was measured on tissue fixed with osmium tetroxide and digested in urea solution (Robelin, 1981). Cell diameters greater than $12.5 \mu \mathrm{m}$ were measured with the Optimas software, and the mean volume was calculated from the individual cell volumes.

LPL activity was measured in AT using an artificial emulsion containing ${ }^{3} \mathrm{H}$-triolein after a detergent (Deoxycholate-Nonidet $\mathrm{P}_{40}$; Sigma Chemical, Saint-QuentinFallavier, France) extraction procedure (Faulconnier et al., 1994). The activities of glucose-6-phosphate dehydrogenase (G6PDH), malic enzyme (ME), fatty acid synthase (FAS) and glycerol-3-phosphate dehydrogensase (G3PDH) were assayed spectrophotometrically in AT as described previously (Faulconnier et al., 2004). Enzyme activities were expressed either as nmol of released fatty acids (LPL) or as nmol of reduced (G6PDH, ME) or oxidized (FAS, G3PDH) nucleotides per min and per $10^{6}$ adipocytes.

\section{Statistical analyses}

The data presented in Tables 1 and 2 and Figure 2 were analysed using the ANOva procedure of the statistical package (Statistical Analysis Systems Institute (SAS), 1985). Differences between the two treatments were tested using the PLSD Fisher test. Values were considered to be significantly different if $P$ values were less than 0.05 , and tendencies with $P<0.10$ are also indicated.

The data presented in Tables 3 and 4 were analysed using the MIXED procedure of the SAS statistical package. The model accounted for diet treatment (D), AT sites (S) and their interaction $(D \times S)$ as fixed effects, and animal withindiet treatment was the random effect. A comparison of means was performed using the LSMEANS statement of the MIXED procedure. Differences between diet treatments and/or AT sites were considered significant if $P$ values were less than 0.05 .

The data illustrated in Figure 1 were analysed using the MIXED procedure of the SAS statistical package. The model accounted for the diet treatment (D), age of the steers (A) and their interaction $(D \times A)$ as fixed effects, and animal within diet treatment was the random effect. A comparison of means was performed using the LSMEANS statement of 
Faulconnier, Ortigues-Marty, Delavaud, Dozias, Jailler, Micol and Chilliard

the MIXED procedure. Differences between diet treatment and/or age of the steers were considered significant if $P$ values were less than 0.05 .

\section{Results}

Effect of the diet and grazing on body weight, average daily gain and body fat weight

Growth performance remained similar across treatment groups. Final body weight (BW) and average daily gain before slaughtering did not differ between the two (Experiment 1) or the three (Experiment 2) treatment groups (Table 1). Total fat, internal AT and perirenal AT were not significantly affected by nutritional treatments (Table 1).

Table 2 Effect of the diet and grazing on plasma metabolite and hormone concentrations in Charolais steers before slaughter in Experiments 1 and 2

\begin{tabular}{|c|c|c|c|c|c|}
\hline & \multicolumn{2}{|c|}{ Grass } & \multicolumn{2}{|c|}{ Maize } & \multirow{2}{*}{$\begin{array}{c}\text { Treatmen } \\
\text { effect } \\
p<\end{array}$} \\
\hline & Cut & Grazed & Silage & s.e. & \\
\hline \multicolumn{6}{|l|}{ Experiment 1} \\
\hline NEFA (mmol/l) & & $0.587^{\mathrm{A}}$. & $0.248^{\mathrm{B}}$ & 0.040 & 0.001 \\
\hline Glucose $(\mathrm{mmol} / \mathrm{l})$ & & 4.93 & 4.75 & 0.12 & 0.69 \\
\hline Insulin ( $\mu \mid U / m l)$ & & 19.3 & 19.1 & 1.52 & 0.95 \\
\hline Leptin (ng/ml) & & $3.12^{\mathrm{A}}$ & $4.27^{\mathrm{B}}$ & 1.41 & 0.05 \\
\hline \multicolumn{6}{|l|}{ Experiment 2} \\
\hline NEFA (mmol/l) & $0.331^{\mathrm{A}}$ & $0.618^{\mathrm{B}}$ & $0.305^{A}$ & 0.076 & 0.013 \\
\hline Glucose $(\mathrm{mmol} / \mathrm{l})$ & $4.39^{A}$ & $5.27^{\mathrm{B}}$ & $5.29^{B}$ & 0.14 & 0.001 \\
\hline Insulin $(\mu \mid \mathrm{J} / \mathrm{ml})$ & $17.7^{\mathrm{A}}$ & $17.0^{\mathrm{A}}$ & $24.2^{\mathrm{B}}$ & 1.52 & 0.008 \\
\hline Leptin (ng/ml) & $6.23^{\mathrm{ABa}}$ & $3.81^{\mathrm{Bb}}$ & $6.80^{\mathrm{Aa}}$ & 2.93 & 0.12 \\
\hline
\end{tabular}

Effect of the diet and grazing on plasma metabolites and hormones

During the first experiment, plasma NEFA concentrations were higher $(+137 \%)$ in steers grazing grass compared with those fed maize silage (Table 2), while plasma glucose and insulin concentrations remained similar between the two groups.

During the second experiment, plasma NEFA concentrations were also higher $(+103 \%)$ in steers grazing grass compared with those fed maize silage, whereas plasma insulin concentrations were lower $(-30 \%)$ in the grazing steers (Table 2). Plasma glucose concentrations did not differ between steers grazing grass and those fed maize silage. Steers fed cut grass showed lower plasma glucose and insulin concentrations $(-17 \%$ and $-27 \%$ for glucose and insulin, respectively) than steers fed maize silage (Table 2), whereas plasma NEFA concentrations were similar. Grazing per se (i.e. grazed grass $v$. cut grass diets) led to an increase in plasma glucose $(+20 \%)$ and NEFA $(+87 \%)$ concentrations but had no significant effect on plasma insulin concentrations.

At slaughter, plasma leptin concentrations were lower $(-27 \%$ and $-44 \%$ in the first and second experiments, respectively) in steers grazing grass than in steers fed maize silage (Table 2). In the second experiment, plasma leptin concentrations were similar between steers fed cut grass and steers fed maize silage, whatever the age of the steers (Table 2 and Figure 1). Grazing per se decreased $(-44 \%$ and $-39 \%$ at 840 and 964 days of age, respectively) plasma leptin concentrations. Moreover, whatever the diet, leptinaemia was significantly higher in older than in younger steers (Figure 1).

\section{Effect of the diet, grazing and adipose tissue site on adipose cell size}

During the first and the second experiments, the volume of adipocytes in perirenal and intermuscular AT was not significantly affected by the nature of the diet (Tables 3 and 4 ). Adipocyte number $\left(\times 10^{9}\right)$ expressed per total perirenal AT

Table 3 Effect of the diet and adipose tissue site on adipose tissue lipogenic enzyme activities and adipose cell volume in Charolais steers ( $\mathrm{n}=24)$ in experiment 1 (activities are expressed as $\mathrm{mmol} / \mathrm{min}$ per $10^{6}$ adipocytes)

\begin{tabular}{|c|c|c|c|c|c|c|c|}
\hline \multirow[b]{3}{*}{ Diet $(D)$} & \multicolumn{4}{|c|}{ Adipose tissue site $(\mathrm{S})$} & \multirow[b]{3}{*}{ s.e. } & & \\
\hline & \multicolumn{2}{|c|}{ IMAT } & \multicolumn{2}{|c|}{ PRAT } & & \multicolumn{2}{|c|}{$P<<^{\ddagger}$} \\
\hline & Grazed grass & Maize silage & Grazed grass & Maize silage & & D & $S$ \\
\hline Adipocyte volume (pl) & $1420^{A}$ & $1182^{\mathrm{A}}$ & $1737^{\mathrm{B}}$ & $1402^{\mathrm{AB}}$ & 159 & 0.18 & 0.008 \\
\hline Lipoprotein lipase & $50^{\mathrm{A}}$ & $106^{\mathrm{B}}$ & $45^{\mathrm{A}}$ & $103^{\mathrm{B}}$ & 12 & 0.002 & 0.63 \\
\hline Glucose-6-phosphate dehydrogenase & $579^{A}$ & $1736^{\mathrm{B}}$ & $589^{A}$ & $1995^{\mathrm{B}}$ & 195 & 0.001 & 0.38 \\
\hline Malic enzyme & $168^{\mathrm{A}}$ & $333^{\mathrm{B}}$ & $66^{\mathrm{C}}$ & $159^{\mathrm{A}}$ & 28 & 0.001 & 0.001 \\
\hline Fatty acid synthase & $33^{A}$ & $54^{\mathrm{B}}$ & $28^{\mathrm{A}}$ & $71^{\mathrm{B}}$ & 10 & 0.017 & 0.41 \\
\hline Glycerol-3-phosphate dehydrogenase & $3842^{\mathrm{A}}$ & $5820^{B}$ & $3040^{\mathrm{A}}$ & $7044^{\mathrm{B}}$ & 924 & 0.014 & 0.81 \\
\hline
\end{tabular}

Abbreviations are: IMAT = intermuscular adipose tissue; PRAT = perirenal adipose tissue.

$A, B$ Indicate that values with different superscript letters within the same row are significantly different $(P<0.05)$.

${ }^{\ddagger}$ There was no significant interaction between diet and adipose tissue site $(P>0.10)$. 
was not affected by the nature of the diet (experiment 1 : $7.1 \pm 0.8$ and $6.9 \pm 1.4$ in maize silage and grazed grass groups, respectively, $P=0.93$; experiment 2: $7.1 \pm 1.2$, $5.4 \pm 0.6$ and $5.4 \pm 0.2$ in maize silage, grazed grass and cut grass-fed groups, respectively, $P=0.24)$. Grazing per se had no significant effect on adipocyte volume whatever the AT site studied (Table 4), nor on adipocyte number expressed per total perirenal AT $(P=0.98)$. Adipocyte volume was significantly affected by AT site (Tables 3 and 4) and was globally greater in perirenal than in intermuscular and subcutaneous AT (Figure 2).

Effect of the diet, grazing and adipose tissue site on lipogenic enzyme and lipoprotein lipase activities The lipogenic enzyme activities measured in Experiment 1 (Table 3) were similar in the perirenal and intermuscular AT (except for ME activity, which was lower in perirenal AT), whereas there was a significant effect of AT site in Experiment 2 with greater activities in subcutaneous and/or perirenal AT than in intermuscular AT, whatever the nature of the diet (Figure 2) (except for ME activity which was again lower in perirenal AT).

During the first experiment, LPL, G6PDH, ME, FAS and G3PDH activities were lower in grazing steers compared with maize silage-fed animals, both in perirenal $(-56 \%$, $70 \%, 58 \%, 61 \%$ and $57 \%$, respectively) and intermuscular $(-53 \%, 67 \%, 50 \%, 39 \%$ and $34 \%$, respectively) AT (Table 3).

In the second experiment, LPL, G6PDH, ME, FAS and G3PDH activities were significantly affected by the nature of the diet (Table 4). They were lower (from $-22 \%$ to $-74 \%$ ) in perirenal and subcutaneous AT with the two grass diets compared with the maize silage diet, except for FAS activity in perirenal AT (Table 4). Similar trends were observed in intermuscular AT, although the effects on ME, FAS and G3PDH activities were less marked, especially when comparing grazed grass to maize silage diets (Table 4). Grazing per se had no significant effect on lipogenic enzymes in the three AT sites, except for G6PDH in subcutaneous AT, ME in intermuscular AT and G3PDH in subcutaneous and intermuscular AT, which all showed increased activity (from $50 \%$ to $99 \%$ ) under the grazing treatment (Table 4).

\section{Discussion}

This study shows that the activity of lipogenic enzymes involved in NADPH generation for de novo lipogenesis (G6PDH, ME), FA synthesis and uptake (FAS and LPL, respectively) and esterification (G3PDH) were all lower in Charolais steers fed a cut grass diet compared with a maize silage diet in the three AT sites studied, although the effects were less marked in intermuscular AT. Depot-specific differences in lipogenic enzymes were observed, with greater activities (except for ME activity) in subcutaneous and/or perirenal AT than in intermuscular AT, which is consistent 
with previous reports (Whitehurst et al., 1981; Mendizabal et al., 1999) in different breeds of steers. However, the absence of interaction between adipose depot and dietary treatments for most enzymes indicates that diet-induced

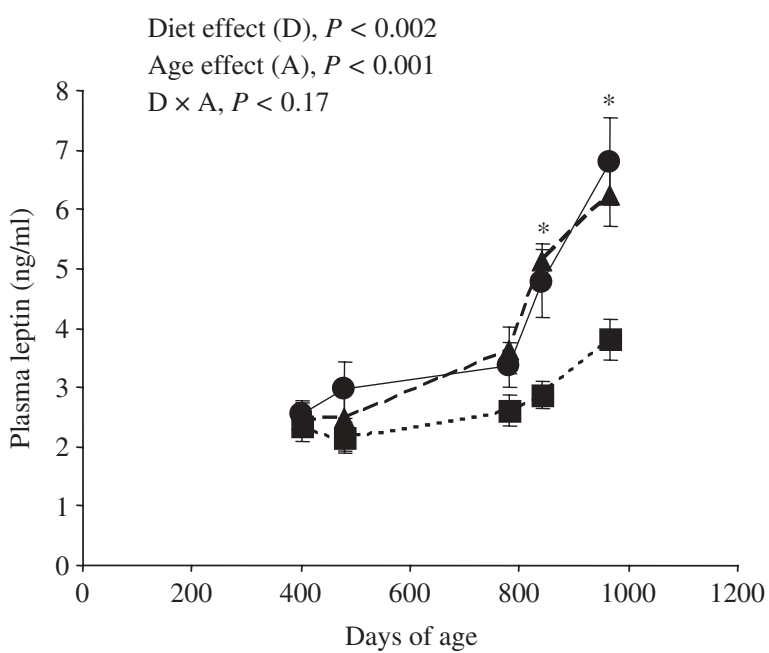

Figure 1 Effect of nature of forage [maize silage $(\mathbf{O})$; grazed grass $(\mathbf{\square})$; cut grass $(\mathbf{\Lambda})]$ and of age of the steers on plasma leptin concentrations (Experiment 2, mean \pm s.e., eight steers per group). *Plasma leptin concentrations were significantly $(P<0.05)$ lower in steers grazing grass than in steers of the same age fed maize silage or cut grass. changes in lipogenic enzyme activities are consistent across adipose depots. The absence of any difference across treatment groups in final BW, average daily gains before slaughtering, total fat weight and AT weight, cell size and adipocyte number suggests that the effects observed on lipogenic activities were associated with the nature of the diet (cut grass $v$. maize diets) and not to differences in available net energy. To our knowledge, there is no published work comparing the effects of grass-based $v$. maize silage diets on AT lipogenesis in isoenergetically fed cattle. Our results are, however, in agreement with Okine and Arthur (1997) who showed that acetyl CoA carboxylase (ACC) and FAS activities and the rate of FA esterification were $34 \%, 28 \%$ and $47 \%$ lower, respectively, in the subcutaneous AT of ewes isoenergetically fed roughage $v$. concentrate diets having the same energy density. Thus, the present study shows in cattle that lipogenic activities may be associated not only with the energy available for growth but also with the type of feed.

Among different putative mechanisms, the decrease in AT lipogenesis observed in the present study is probably at least partly due to differences in FA composition between the experimental diets. Indeed, grass-based diets generally present a lower proportion of oleic acid 18:1 (n-9) and linoleic acid 18:2 (n-6) and higher $\alpha$-linolenic acid 18:3 (n-3) than the concentrate-based or maize-silage-based diets
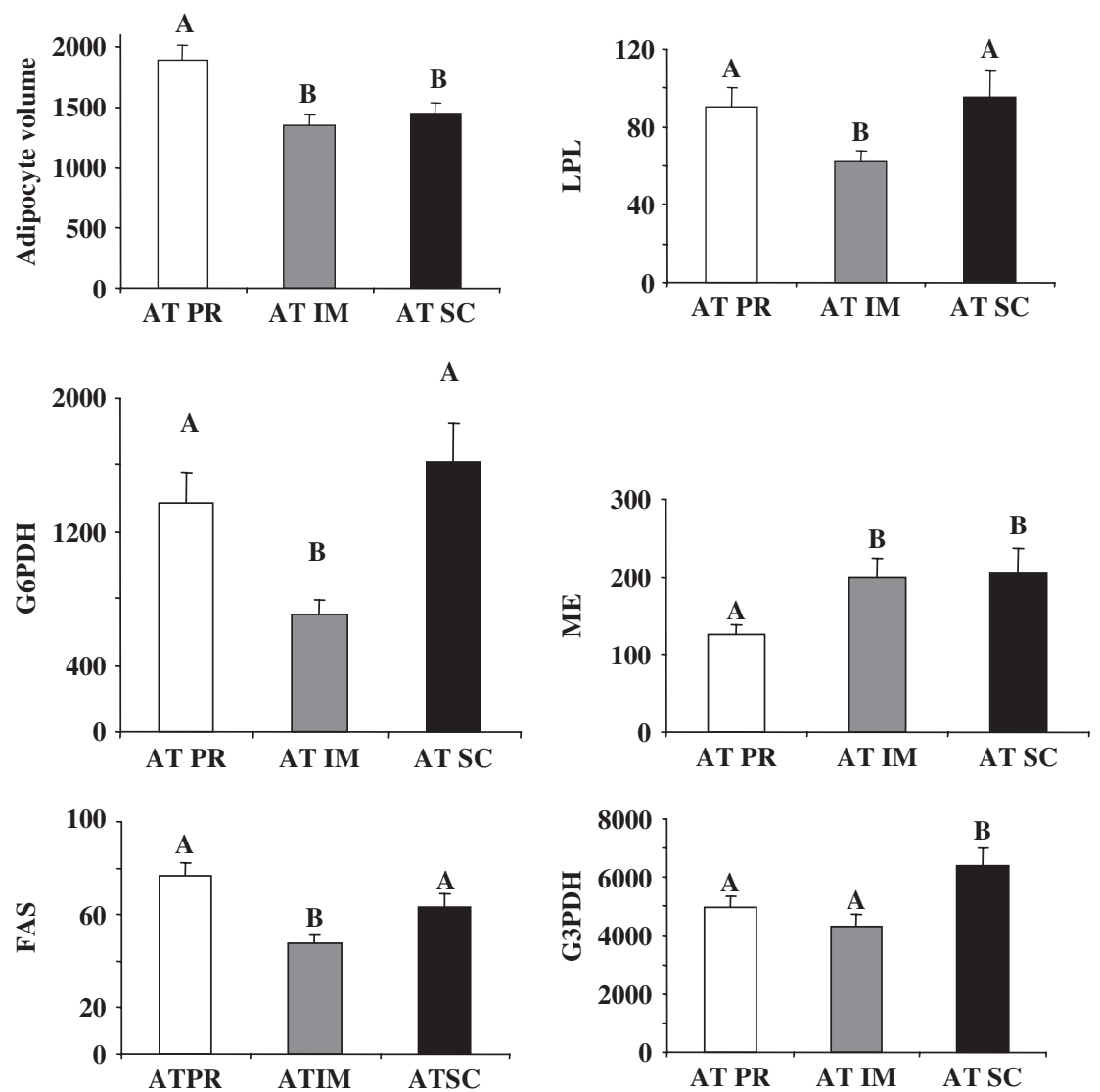

Figure 2 Lipogenic enzyme activities (nmol/min per $10^{6}$ adipocytes) and adipose cell size (pl) in perirenal (PR), intermuscular (IM) and subcutaneous (SC) adipose tissues (AT) in steers (Experiment 2, mean \pm s.e., 24 steers). ${ }^{A, B}$ Means with different superscript letters are significantly different $(P<0.05)$. 
(Ferlay et al., 2006). Literature data on ruminant AT have shown that diets supplemented with different unsaturated FA inhibited FA synthesis or lipogenic activities, the effects being more or less marked according to experiment duration, to the amount of the dietary lipid supplements, and to the degree of protection against ruminal biohydrogenation (see Chilliard, 1993 for a review). Furthermore, Fickova et al. (1998) showed, in rat epididymal adipocytes, that higher dietary levels of (n-3) PUFA increased the lipolytic response relative to ( $n-6)$ PUFA diets while diminishing insulin-stimulated glucose transport and lipogenesis. In pigs, Mourot et al. (1994) observed that the elevation of dietary linoleic supply 18:2 (n-6) increased ACC, ME and G6PDH activities in subcutaneous and perirenal AT. Thus, it is likely that the lower lipogenic enzyme activities observed in the present study in AT from cut-grass-fed steers was partly related to the more-abundant 18:3 (n-3) and lessabundant 18:2 (n-6) in grass diet compared with maize silage diet. Indeed, several studies have shown that the inclusion of pasture compared with concentrates in bovine diets led to an increase in proportion of PUFA, PUFA/SFA ratio and 18:3 (n-3) percentage and a decrease in 18:2 $(n-6)$ percentage in subcutaneous and/or intermuscular AT (Realini et al., 2004; Noci et al., 2005). Pasture feeding (as compared with concentrate) also increased bovine subcutaneous AT concentrations of several trans isomers of 18:1 and 18:2 (Noci et al., 2005; Dannenberger et al., 2005), which could have antilipogenic effects (Faulconnier et al., 2006).

Another explanation for the lower lipogenic activities in steers fed cut grass compared with maize silage could be the absence of starch as compared with the maize diet. Maize is known to increase whole-body glucose turnover (Ortigues-Marty et al., 2003) through an enhanced supply of either gluconeogenic precursor or absorbed glucose (Chilliard et al., 1998), both stimulating insulin secretion (Gross et al., 1990). These known effects are coherent with the increase in plasma glucose and insulin concentrations observed in the present study in steers fed maize silage compared with cut grass and could result in higher lipogenic enzyme and LPL activities in AT. Indeed, although glucose is of minor importance as a carbon source for FA synthesis, the oxidation of glucose via the pentose phosphate pathway is an important source of reduced NADP, whereas its oxidation via glycolysis contributes to 3-glycerol phosphate for FA esterification in ruminant AT (Ballard et al., 1972; Janes et al., 1985). It could thus be hypothesized that lipogenic potential (as measured in vitro) was increased by glucose and insulin in the maize silage group and/or decreased by PUFA in the grass-fed groups, but that this potential was not expressed in vivo because of the management of animals at similar growth rates.

Leptin is a hormone primarily secreted by white AT, which is implicated in the regulation of food intake, energy expenditure and body fat stores and is modulated by dietary macronutrient composition (see Havel, 2004 for a review). In cattle, plasma leptin levels are closely linked to AT cellularity, body condition score and nutritional state (see Chilliard et al., 2005 for a review). To our knowledge, there is no published work on the effects of the grass diet $v$. maize silage diet on plasma leptin concentrations in ruminants. In the present study, the nature of the forage (cut grass $v$. maize silage diets) did not affect significantly plasma leptin concentration, regardless of the age of the steers. This is in agreement with the lack of variation in AT weight and cell size (and total adipocyte number in perirenal AT) between steers fed cut grass and maize silage, which had similar growth rates. Furthermore, no effect of feeding sunflower seeds or corn oil was observed on leptinaemia in growing or beef cattle (see Chilliard et al., 2005 for a review). The apparent contradiction between the decrease in AT lipogenic enzymes and LPL activities and the absence of variation in leptinaemia in steers fed cut grass (compared with maize silage) could be explained by the fact that lipogenic activities reflect the short-term effect of daily nutritional status while leptinaemia reflects long-term effects of feeding level and is strongly related to body fatness, which did not differ between the different groups of steers, in the present study.

Whatever the diet, plasma leptin concentrations were significantly higher in the older than in younger steers (Figure 1), probably due to the increase in body fatness during the ageing process. These data corroborate previous studies (Vega et al., 2002; Higashiyama et al., 2003; Hersom et al., 2004) showing increased circulating leptin levels during fattening in heifers and steers. The late increase of leptinaemia with age in Charolais steers (from 28-32 months of age in the present study, Figure 1) compared with Holstein or Japanese Black steers (from 16 to 18 months of age, Vega et al., 2002; Higashiyama et al., 2003) could be a breed-related difference due to an earlier lipid deposition in the early-maturing Holstein and Japanese Black breeds than in the late-maturing Charolais breed.

Grazing per se (grazing $v$. cut grass diets) either did not affect lipogenic enzyme activities in the three AT sites or even increased some of them (G3PDH and G6PDH), whereas it decreased plasma leptin concentrations from the older steers and increased plasma glucose and NEFA concentrations without affecting AT weight and adipose cell size. These data on lipogenesis were unexpected, since previous studies in rat AT (Applegate et al., 1984; Ladu et al., 1991) showed that physical exercise lowered fat gain and lipogenic enzyme activities. However, the decrease in plasma leptin and the increase in plasma NEFA levels in grazing steers are in agreement with previous studies in physical exercise-trained rats (Nara et al., 1999, Faulconnier et al., 2004). An increase in $\beta$-adrenergic stimulation occurring during physical activity (Van Aggel-Leijssen et al., 2001) could explain the increase in plasma NEFA and the decrease in plasma leptin (Chilliard et al., 2001) observed in the present study. Furthermore, the decrease in leptinaemia with grazing could have increased the energetic efficiency of these steers (see Chilliard et al. (2005) for review), which would compensate the increase in 
Faulconnier, Ortigues-Marty, Delavaud, Dozias, Jailler, Micol and Chilliard

energy expenditure generally observed during physical activity (Lobley, 1990), and thus explain, at least in part, why grazing had no effect on AT weight and lipogenic activities in the present study.

In conclusion, this is the first study to report that steers reared at similar growth rates and slaughtered at the same age show significantly lower lipogenic enzyme activities in perirenal, intermuscular and subcutaneous AT when fed cut grass compared with a maize silage diet. Plasma insulin and glucose concentrations were also decreased whereas plasma leptin concentrations and adipose cell size were similar. Grazing per se did not affect lipogenic enzyme activities in the three AT sites studied, whereas it decreased plasma leptin concentrations in the older steers (from 840 days) and increased plasma NEFA and glucose concentrations without affecting plasma insulin concentrations. Future studies using specific nutrient infusions and/or measurement of energy metabolism and expenditure are needed to unravel the mechanisms responsible for the respective effects of forages (maize, grass) and the physical activity of grazing on the regulation of bovine AT lipogenesis and to investigate the molecular events that could be involved in these effects. Moreover, to confirm our results on the effect of grazing on AT lipogenesis and leptinaemia, it would be useful to test the influence of more intensive and longer physical activity in grazing steers.

\section{Acknowledgements}

The authors are grateful for the expert contributions from the staff of the two INRA experimental stations (Le Pin-au-Haras and Intrabois, Theix) for running the experiments, to the INRA Theix Slaughterhouse for slaughtering the animals, to C. Labonne, D. Bany, M. Tourret and A. Thomas for technical laboratory assistance and to $\mathrm{M}$. Bonnet for helpful discussions. This study received financial support from the French Fonds National d'Aménagement et du Développement du Territoire.

\section{References}

Applegate EA, Upton DE and Stern JS 1984. Exercise and detraining: effect on food intake, adiposity and lipogenesis in Osborne-Mendel rats made obese by a high-fat diet. The Journal of Nutrition 114, 447-459.

Ballard FJ, Filsell $\mathrm{OH}$ and Jarret IG 1972. Effect of carbohydrate availability on lipogenesis in sheep. The Biochemistry Journal 226, 193-200.

Bonnet $\mathrm{M}$, Faulconnier $\mathrm{Y}$, Hocquette JF, Bocquier $\mathrm{F}$, Leroux $\mathrm{C}$, Martin $\mathrm{P}$ and Chilliard Y 2004. Nutritional status induces divergent variations of GLUT4 protein content, but not lipoprotein lipase activity, between adipose tissues and muscle in adult cattle. The British Journal of Nutrition 92, 617-625.

Chilliard $Y$ 1993. Dietary fat and adipose tissue metabolism in ruminants, pigs, and rodents: a review. Journal of Dairy Science 76, 3897-3931.

Chilliard Y and Robelin J 1985. Activity of lipoprotein lipase in different adipose deposits and its relation to adipocyte size in the cow during fattening or early lactation. Reproduction Nutrition Development 25, 287-293.

Chilliard Y, Bocquier F and Doreau M 1998. Digestive and metabolic adaptations of ruminants to undernutrition, and consequences on reproduction. Reproduction Nutrition Development 38, 131-152.

Chilliard Y, Bonnet M, Delavaud C, Leroux C, Djiane J and Bocquier F 2001. Leptin in ruminants. Gene expression in adipose tissue and mammary gland, and regulation of plasma concentration. Domestic Animal Endocrinology 21, 271-295.

Chilliard Y, Delavaud C and Bonnet M 2005. Leptin expression in ruminants: Nutritional and physiological regulations in relation with energy metabolism. Domestic Animal Endocrinology 29, 3-22.

Dannenberger D, Nuernberg K, Nuernberg G, Scollan N, Steinhart $H$ and Ender $K$ 2005. Effect of pasture $v$. Concentrate diet on CLA isomer distribution in different tissue lipids of beef cattle. Lipids 40, 589-598.

Delavaud C, Ferlay A, Faulconnier Y, Bocquier F, Kann G and Chilliard Y 2002. Plasma leptin concentration in adult cattle: Effect of breed, adiposity, feeding level, and meal intake. Journal of Animal Science 80, 1317-1328.

Faulconnier Y, Thévenet M, Fléchet J and Chilliard Y 1994. Lipoprotein lipase and metabolic activities in incubated bovine adipose tissue explants: effects of insulin, dexamethasone, and fetal bovine serum. Journal of Animal Science 72, 184-191.

Faulconnier Y, Arnal MA, Patureau Mirand P, Chardigny JM and Chilliard Y 2004. Isomers of conjugated linoleic acid decrease plasma lipids and stimulate adipose tissue lipogenesis without changing adipose weight in post-prandial adult sedentary or trained Wistar rats. The Journal of Nutrition and Biochemistry 15, 741-748.

Faulconnier Y, Roy A, Ferlay A, Chardigny JM, Durand D, Lorenz S, Gruffat D and Chilliard $Y$ 2006. Effect of dietary supply of butters rich either in trans-1018:1 or in trans-11-18:1 plus cis-9, trans-11-18:2 on rabbit adipose tissue and liver lipogenic activities. The British Journal of Nutrition 96, 461-468.

Ferlay $A$ and Chilliard $Y$ 1999. Effects of the infusion of non-selective $\beta-$, and selective $\beta 1$ - or $\beta 2$-adrenergic agonists, on body fat mobilization in underfed or overfed non-pregnant heifers. Reproduction Nutrition Development 39, 409-421.

Ferlay A, Martin B, Pradel P, Coulon JB and Chilliard Y 2006. Influence of grassbased diets on milk fatty acid composition and milk lipolytic system in Tarentaise and Montbéliarde cow breeds. The Journal of Diary Science 89, 4026-4041.

Fickova M, Hubert P, Crémel G and Leray C 1998. Dietary (n-3) and (n-6) polyunsaturated fatty acids rapidly modify fatty acid composition and insulin effects in rat adipocytes. Journal of Nutrition 128, 512-519.

French P, Stanton C, Lawless F, O'Riordan EG, Monahan FJ, Caffrey PJ and Moloney P 2000. Fatty acid composition, including conjugated linoleic acid, of intramuscular fat from steers offered grazed grass, grass silage, or concentrate-based diets. Journal of Animal Science 78, 2849-2855.

Geay Y, Bauchart D, Hoquette JF and Culioli C 2001. Effect of nutritional factors on biochemical, structural and metabolic characteristics of muscles in ruminants, consequences on dietetic value and sensorial qualities of meat. Reproduction Nutrition Development 41, 1-26.

Gilbert CD, Lunt DK, Miller RK and Smith SB 2003. Carcass, sensory, and adipose tissue traits of Brangus steers fed casein-formaldehyde-protected starch and/or canola lipid. Journal of Animal Science 81, 2457-2468.

Gross KL, Harmon DL, Minton JE and Avery TB 1990. Effects of isoenergetic infusions of propionate and glucose on portal-drained visceral nutrient flux and concentrations of hormones in lambs maintained by total intragastric infusion. Journal of Animal Science 68, 2566-2574.

Havel PJ 2004. Update on adipocyte hormones: regulation of energy balance and carbohydrate/lipid metabolism. Diabetes 53, S143-S151.

Hersom MJ, Wettemann RP, Krehbiel CR, Horn G and Keisler DH 2004. Effect of live gain of steers winter grazing: III. Blood metabolites and hormones during feedlot finishing. Journal of Animal Science 82, 2059-2068.

Higashiyama $Y$, Abe $H$, Hayashi $M$ and Hodate $K$ 2003. The comparison of plasma level and mRNA expression of leptin from Japanese Black steers and Holstein steers. Livestock Production Science 81, 247-255.

Institut National de la Recherche Agronomique 1978. Alimentation des Ruminants. INRA Publications, Versailles.

Janes AN, Weekes TEC and Armstrong DG 1985. Insulin action and glucose metabolism in sheep fed on dried-grass or ground, maize silage-based diets. The British Journal of Nutrition 54, 459-471.

Ladu MJ, Kapsas H and Palmer WK 1991. Regulation of lipoprotein lipase in muscle and adipose tissue during exercise. Journal of Applied Physiology 71, 404-409.

Lobley GE 1990. Energy metabolism reactions in ruminant muscle: responses to age, nutrition and hormonal status. Reproduction Nutrition Development 30, 13-34. 
Mendizabal JA, Alberti P, Eguinoa P, Arana A, Soret B and Purroy A 1999. Adipocyte size and lipogenic activities in different adipose tissue in steers of local Spanish breeds. Animal Science 69, 115-121.

Mourot J, Peiniau P and Mounier A 1994. Effets de l'acide linoléique alimentaire sur l'activité des enzymes de la lipogenèse dans les tissus adipeux chez le porc. Reproduction Nutrition Development 34, 213-220.

Nara M, Kanda T, Tsuhui S, Inukai T, Umeda T, Inoue S and Kobayashi I 1999. Reduction of leptin precedes fat loss from running exercise in insulin-resistant rats. Experimental and Clinical Endocrinology and Diabetes 107, 431-434.

Noci F, Monahan FJ, French $P$ and Moloney AP 2005. The fatty acid composition of muscle fat and subcutaneous adipose tissue of pasture-fed beef heifers: influence of the duration of grazing. Journal of Animal Science 83, 1167-1178.

Okine EK and Arthur PF 1997. Effects of isoenergetic barley grain and alfalfa pellets diets on in vitro lipogenesis and lipogenic enzyme activities in subcutaneous adipose tissue from sheep. Canadian Journal of Animal Science 77, 173-175.

Ortigues-Marty I, Vernet J and Majdoub L 2003. Whole body glucose turnover in growing and non-productive adult ruminants: meta-analysis and review. Reproduction Nutrition Development 43, 371-383.

Realini CE, Duckett SK, Brito GW, Dalla Rizza M and De Mattos D 2004. Effect of pasture $v$. concentrate feeding with or without antioxidants on carcass characteristics, fatty acid composition, and quality of Uruguayan beef. Meat Science 66, 567-577.
Robelin J 1981. Cellularity of bovine adipose tissues: developmental changes from 15 to 65 percent mature weight. Journal of Lipid Research 22, 452-457.

Robelin J and Geay Y 1977. Estimation de la composition de la carcasse des taurillons à partir de la composition de la 6ème côte. Bulletin Technique CRZV Theix 22, 41-45.

Schoonmaker JP, Fluharty FL and Loerch SC 2004. Effect of source and amount of energy and rate of growth in the growing phase on adipocyte cellularity and lipogenic enzyme activity in the intramuscular and subcutaneous fat depots of Holstein steers. Journal of Animal Science 82, 137-148.

Statistical Analysis Systems Institute 1985. SAS/STAT, 6th edition. SAS Institute Inc., Cary NC, USA.

Van Aggel-Leijssen DP, Saris WH, Homan M and Van Baak MA 2001. The effect of exercise training on beta-adrenergic stimulation of fat metabolism in obese men. International Journal of Obesity and Related Metabolic Disorders 25, 16-23.

Vega RA, Lee HG, Kuwayama H, Matsunaga N and Hidari H 2002. Age-related changes in plasma leptin from early growing to late finishing stages of castrated Holstein steers: Utilizing multi-species leptin RIA. Australian Journal of Animal Science 15, 725-731.

Whitehurst GB, Beitz DC, Cianzio D and Topel DG 1981. Fatty acid synthesis from lactate in growing cattle. The Journal of Nutrition 111, 1454-1461. 